\title{
Brain Based Learning Efektif Meningkatkan Kemampuan Pemecahan Masalah Konsep Bilangan Anak Usia Dini
}

\author{
Putri Setyaningtyas ${ }^{\bowtie}$, Harun Harun ${ }^{2}$ \\ Pendidikan Anak Usia Dini, Universitas Negeri Yogyakarta \\ DOI: $\underline{10.31004 / o b s e s i . v 4 i 2.479}$
}

\begin{abstract}
Abstrak
Pengetahuan matematika awal khususnya konsep bilangan bagi anak usia dini sangat penting, karena nantinya dapat membantu anak memecahkan masalah di dalam kehidupan sehari-harinya. Tujuan penelitian ini menguji efektivitas brain based learning (BBL) terhadap kemampuan pemecahan masalah konsep bilangan pada anak usia dini. Penelitian ini merupakan penelitian kuantitatif quasi eksperimen dengan nonequivalent groups pretestposttest control design. Sampel sejumlah 42 anak yang berusia 5-6 tahun. Teknik pengumpulan data berupa tes yang disesuaikan dengan karakter anak usia dini. Pengujian hipotesis menggunkan statistik parametrik, kemudian dihitung menggunakan independent sample t-test dan ANOVA test, $(\rho<0,05)$. Hasil analisis data menunjukkan, Pertama, hasil kelompok eksperimen melampaui hasil kelompok kontrol dalam keseluruhan komponen pemecahan masalah konsep bilangan. Kedua, adanya peningkatan nilai kelompok eksperimen pada saat post-test. Ketiga, BBL memberikan efek yang besar pada keseluruhan komponen. Oleh karena itu, BBL sangat tepat diterapkan dalam pembelajaran yang berkaitan dengan kognitif seperti pemecahan masalah konsep bilangan.
\end{abstract}

Kata Kunci: pembelajaran berbasis otak; pemecahan masalah; konsep bilangan; anak usia dini.

\begin{abstract}
The basic knowledge of Mathematics is very important to be taught in early childhood, since it can help the children to solve the problems in their daily live. This study aimed to test the effectiveness of brain-based learning (BBL) in solving the concept of number problems in early childhood. The type of the research was quantitative research by implementing quasiexperimental method with non-equivalent groups: pretest-posttest control design. The samples of 42 children aged 5-6 years. The data was collected in form of tests that were suitable with the children's character. The hypothesis testing was conducted by using parametric statistics, and calculated by using independent sample t-tests and ANOVA tests, $(\rho<0.05)$. The results of the data analysis were as follows: First, the results of the experimental group exceeded the results of the control group in the whole components of the problem solving concept of numbers. Second, an increase in the value of the experimental group at the post-test. Third, BBL has a large effect on all components. Therefore, BBL is very appropriate to be applied in learning process, especially those related to cognitive issues such as solving the concept of numbers.
\end{abstract}

Keywords: brain based learning; problem solving; concept of number; education; early childhood.

Copyright (c) 2020 Putri Setyaningtyas, Harun Harun

$\triangle$ Corresponding author :

Email Address : putrisetyaningtyas1@gmail.com ( Yogyakarta, Indonesia )

Received 8 March, Accepted 15 March 2020, Published 23 March 2020 


\section{PENDAHULUAN}

Anak seringkali dihadapkan oleh kegiatan yang berhubungan dengan lingkungannya, interaksi tersebut tentunya akan menuntut anak untuk memecahkan masalahnya sendiri. Kemampuan pemecahan masalah merupakan aspek fundamental dalam perkembangan anak usia dini. Xin, Wiles, dan Lin (2008) berpendapat bahwa kemampuan pemecahan masalah merupakan landasan pembelajaran matematika. Pengetahuan tentang matematika awal bagi anak usia dini sangat penting, karena nantinya dapat membantu anak dalam memecahkan masalah di dalam kehidupan sehari-harinya (Polonsky, Freedman, Lesher, \& Morrison, 1995). Konsep pembelajarannya adalah dengan mengaitkan permasalahan yang berasal dari kehidupan nyata kemudian dikembangkan dan distimulasi secara berulang dalam kegiatan sehari-hari. Kemampuan pemecahan masalah yang berkaitan dengan matematika khususnya pada konsep bilangan yang menjadi fokus pada penelitian ini.

Piaget (1977) menyatakan bahwa anak usia prasekolah berada pada tahap praoperasional, yakni pada usia ini anak mulai belajar menggunakan simbol-simbol dalam kehidupan sehari-harinya. Kemampuan pemecahan masalah konsep bilangan berkaitan dengan kemampuan anak dalam memahami simbol matematik. Hak ini tidak berarti bahwa guru harus mengajar dengan selalu menggunakan lembar kerja atau buku kerja setiap saat. Perspektif ini akan menyebabkan sikap negatif untuk keterampilan matematika anak usia dini (Maloney, Schaeffer, \& Beilock, 2013). Ramirez, Gunderson, Levine, \& Beilock (2013) menemukan bahwa anak-anak telah dapat menunjukkan kecemasan matematikanya. Dengan menggunakan teknologi pencitraan otak, ini memungkinkan untuk melihat efek dari kecemasan matematika anak-anak. Ketika tiga guru memberikan tugas secara langsung, diketahui bahwa maanak-anak 'merasa panik' untuk melakukan tugas tersebut. Ini meningkatkan aktivitas di daerah otak yang membuat mereka takut dan secara bersamaan menurunkan aktivitas pemecahan masalah. Efek kecemasan dapat menghambat daya ingat anak. Pembelajaran untuk anak kecil akan lebih bermakna ketika dilakukan secara konkret, sebagai karakteristik pembelajaran anak usia dini yang melalui benda-benda konkret.

Sayangnya, kurangnya variasi dalam kegiatan pembelajaran menjadikan minat anak kurang dalam mengikuti pembelajaran, sehingga materi pembelajaran tidak dapat tersampaikan dengan baik. Kegiatan pembelajaran khususnya pada matematika biasanya diajarkan secara tradisonal, yakni anak pasif hanya duduk diam dan mengerjakan tugas di lembar kerja (Blake, Hurley, \& Arenz, 1995; Rianti, 2016). Selain itu, masih ditemukan kurangnya pemahaman anak tentang ukuran benda, misalnya seperti tinggi-rendah, besarkecil, banyak-sedikit, dan berat-ringan (Fauziddin, 2015). Pemahaman konsep bilangan dapat mulai diajarkan pada anak usia dini melalui media atau benda konkrit yang bisa dilihat, dihitung dan diurutkan (Astuti, 2016).

Oleh karena itu, diperlukan pendekatan pembelajaran yang sesuai dengan permasalahan di atas. Brain based learning (BBL) dapat menjadi solusinya. BBL merupakan sebuah pendekatan pembelajaran yang didasarkan pada struktur dan fungsi otak. Pendekatan ini menekankan pada pembelajaran yang bermakna bukan hanya sekedar hafalan. $B B L$ juga disesuaikan dengan cara kerja otak yang secara alamiah belajar (Jensen, 2008; Tüfekçi \& Demirel, 2009). Penerapan BBL dalam pembelajaran dapat menjadikan anak termotivasi dalam pembelajaran, mengembangkan keterampilan berpikir, serta anak dapat memahami konsep yang lebih mendalam (Chamidiyah, 2015).

Tujuan dari penelitian ini adalah untuk mengetahui efektivitas brain based learning terhadap kemampuan pemecahan masalah konsep bilangan. Hasil penelitian ini diharapkan dapat memberikan masukan untuk pembelajaran matematika awal khususnya konsep bilangan pada anak, mengingat kemampuan pemecahan masalah memiliki peran penting dalam kehidupan anak dan akan menentukan keberhasilan di masa depan. 


\section{METODOLOGI}

Penelitian ini terdapat dua variabel, yaitu variabel independen (brain based learning) dan variabel dependen (kemampuan pemecahan masalah konsep bilangan). Pendekatan yang digunakan adalah kuantitatif jenis quasi eksperimen dengan desain nonequivalent groups pretest-posttest control. Sampel dalam penelitian ini sejumlah 42 anak usia 5-6 tahun yang terbagi menjadi 2 kelompok, yakni 21 anak kelompok eksperimen dan 21 anak kelompok kontrol. Kelompok eksperimen diberi perlakukan dengan brain based learning $(B B L)$ dan kelompok kontrol menggunakan pembelajaran konvensional. Berikut desain penelitiannya :

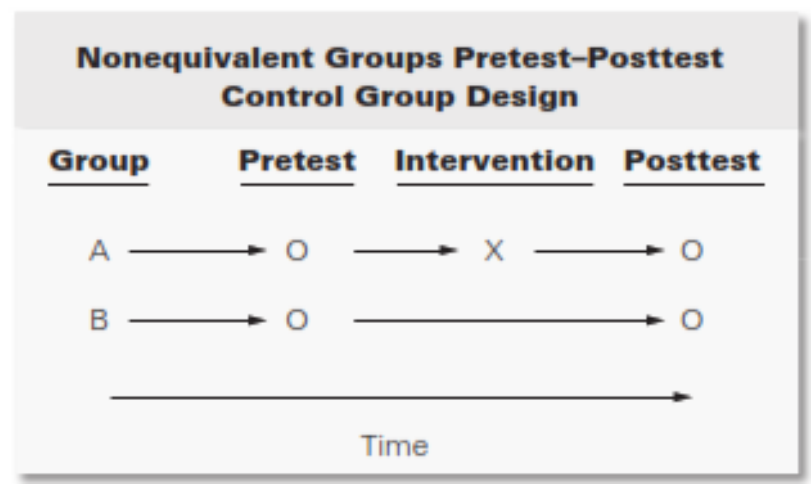

\section{Gambar 1. Desain nonequivalent groups pretest-posttest control}

Keterangan:
A
B
Kelompok eksperimen
$\mathrm{O}_{1}$
: Kelompok kontrol
$\mathrm{O}_{2}$
Pretest
$\mathrm{X}$
Posttest
:Pembelajaran dengan pendekatan $B B L$

Penerapan brain based learning diadaptasi dari Jensen (2008) yang meliputi 7 tahap, yaitu pra-pemaparan, persiapan, inisiasi dan akuisisi, elaborasi, inkubasi dan memasukkan memori, verifikasi dan pengecekkan keyakinan, perayaan dan integrasi. Metode pengumpulan data penelitian menggunakan tes untuk mengukur kemampuan pemecahan masalah konsep bilangan anak usia dini yang diadaptasi dari Smith, Cotton, Hansen, \& Price (2018). Instrumen penelitian ini terdapat 5 komponen dan skala pengukurannya menggunakan rating scale dengan nilai dari 1 sampai 4 (1 menunjukkan anak sudah mampu dan 4 menunjukkan anak belum mampu). Hal ini digunakan karena melihat karakteristik anak usia dini, tes yang diberikan berupa pertanyaan yang nantinya anak menjawab dengan melakukan kegiatan secara langsung (menghitung dengan benda) dan peneliti memberikan nilai.

Teknik analisis data dalam penelitian ini meliputi dua pengujian, yaitu uji prasyarat dan uji hipotesis. Uji prasayarat terdapat uji normalitas dengan kolmogorov smirnov dan uji homogenitas menggunakan levene test for equality of variance. Sedangkan uji hipotesis dalam penelitian ini, menggunakan independent sample t-test dan ANOVA test, $\mathrm{p}<0.05$.

\section{HASIL DAN PEMBAHASAN}

Pada penelitian ini, sejumlah 21 anak pada kelompok kontrol dan 21 anak kelompok eksperimen hadir mengikuti penelitian yang dilaksanakan dalam 6 pertemuan. Peneliti melakukan pretest sebelum memberikan perlakuan untuk mengetahui kondisi awal anak. Setelah diketahui data normal dan homogen, peneliti memberikan treatment pada kelompok 
eksperimen dengan brain based learning dan kelompok kontrol dengan pendekatan konvensional. Ketika pemberian perlakuan telah selesai, pada pertemuan berikutnya peneliti memberikan posttest pada semua kelompok. Hasil penelitian ini akan disajikan dalam bentuk 3 pertanyaan penelitian.

Pertanyaan Penelitian 1: Apakah terdapat perbedaan hasil yang signifikan antara kelompok eksperimen dan kontrol?

Untuk mengetahui efektivitas brain based learning terhadap kemampuan pemecahan masalah konsep bilangan anak digunakan independent sample t-test.

Tabel 1. Hasil post-test kelompok kontrol dan eksperimen

\begin{tabular}{llrrrrrr}
\hline $\begin{array}{c}\text { Komponen } \\
\begin{array}{c}\text { Pemecahan Masalah } \\
\text { Konsep Bilangan }\end{array}\end{array}$ & Group & N & M & $\begin{array}{c}\text { St. } \\
\text { Deviation }\end{array}$ & D.f & t-value & sig \\
\hline 1. Menyebut & Control & 21 & 11.48 & 1.123 & -1.237 & .016 \\
2. Membilang & Experimental & 21 & 11.81 & .512 & & & \\
& Control & 21 & 3.48 & .602 & -2.111 & .002 \\
3. Menghitung & Experimental & 21 & 3.81 & .402 & & & \\
& Control & 21 & 5.29 & 1.231 & -3.677 & .364 \\
4. Mengelompokkan & Experimental & 21 & 6.62 & 1.117 & 40 & & \\
& Control & 21 & 15.14 & 1.493 & -1.419 & .015 \\
5. Membandingkan & Experimental & 21 & 15.67 & .796 & & \\
& Control & 21 & 20.95 & 3.122 & -3.303 & .001 \\
Keseluruhan & Experimental & 21 & 23.43 & 1.434 & & \\
Komponen & Control & 21 & 56.33 & 6.086 & -3.432 & .001 \\
\hline & Experimental & 21 & 61.33 & 2.745 & & & \\
\hline
\end{tabular}

Berdasarkan hasil (Tabel 1) di atas, hasil kelompok ekperimen melampaui hasil kelompok kontrol dalam keseluruhan komponen pemecahan masalah konsep bilangan. Dengan demikian, hipotesis pertama diterima.

Pertanyaan Penelitian 2: Apakah terdapat perbedaan hasil yang signifikan secara statistik pada saat pre-test dan post-test kelompok eksperimen?

Tabel 2. Hasil pre-test dan post-test kelompok eksperimen

\begin{tabular}{lllrrrrr}
\hline $\begin{array}{c}\text { Komponen Pemecahan Masalah Konsep } \\
\text { Bilangan }\end{array}$ & Test & N & M & $\begin{array}{l}\text { St. } \\
\text { Deviation }\end{array}$ & D.f & t-value & sig \\
\hline 1. Menyebut & Pretest & 21 & 10.52 & 1.750 & -3.232 & .000 \\
& Posttest & 21 & 11.81 & .512 & & & \\
2. Membilang & Pretest & 21 & 2.48 & .512 & -9.386 & .001 \\
& Posttest & 21 & 3.81 & .402 & & & \\
3. Menghitung & Pretest & 21 & 4.05 & .740 & -8.795 & .002 \\
& Posttest & 21 & 6.62 & 1.117 & 40 & & \\
4. Mengelompokkan & Pretest & 21 & 12.43 & 1.399 & & -9.220 & .004 \\
5. Membandingkan & Posttest & 21 & 15.67 & .796 & & & \\
& Pretest & 21 & 19.76 & 2.587 & & -5.681 & .041 \\
Keseluruhan Komponen & Posttest & 21 & 23.43 & 1.434 & & \\
& Pretest & 21 & 49.24 & 5.059 & & -9.631 & .040 \\
\hline
\end{tabular}

Hasil (Tabel 2) pengujian menunjukkan bahwa kelompok eksperimen dapat memberikan hasil yang lebih baik dari pada sebelumnya. Kemampuan pemecahan masalah konsep bilangan (menyebut, membilang, menghitung, mengelompokkan, membandingkan) kelompok eksperimen meningkat setelah diberikan treatment. Adanya peningkatan, nilai 
kelompok eksperimen dari 49,24 pada saat pre-test meningkat menjadi 61,33 pada saat posttest. Dengan demikian, hipotesis kedua diterima.

Pertanyaan Penelitian 3: Apakah brain based learning efektif dalam meningkatkan kemampuan pemecahan masalah konsep bilangan?

Dalam menentukan banyaknya perubahan variabel independen (brain based learning) memiliki efek pada kemampuan pemecahan masalah konsep bilangan, digunakan effect size untuk menghitung setiap komponen dan secara keseluruhan. Effect size merupakan ukuran signifikansi hasil penelitian yang berupa ukuran besarnya perbedaan ataupun korelasi dan juga efek dari suatu variabel ke variabel yang lain (Santoso, 2010). Mean dan standard deviation digunakan dalam menghitung effect size. Kemudian hasilnya diintepretasikan berdasarkan deskripsi effect size Cohen (1988).

Tabel 3. Referensi untuk mengintepretasi effect size pada nilai t-test (Cohen, 1988)

\begin{tabular}{ll}
\hline \multicolumn{1}{c}{ Effect size } & \multicolumn{1}{c}{ Interpretations } \\
\hline From 0.2 till less than 0.5 & Small \\
From 0.5 till less than 0.8 & Medium \\
From 0.8 or more & Large \\
\hline
\end{tabular}

Tabel 4. Effect size kemampuan pemecahan masalah konsep bilangan

\begin{tabular}{ll}
\hline \multicolumn{2}{c}{ Komponen Pemecahan Masalah Konsep } \\
Bilangan
\end{tabular}

Berdasarkan hasil (tabel 4) srategi dan teknik brain based learning yang diadaptasi kedalam pembelajaran untuk meningkatkan kemampuan pemecahan masalah konsep bilangan anak usia dini memiliki efek yang positif. Brain based learning memberikan efek yang besar pada keseluruhan komponen. Hal ini terlihat pada effect size 1.059 yang berarti d $>0.08$ tergolong "large". Oleh karena itu, hal ini memberikan bukti yang cukup untuk mendukung hipotesis ketiga.

Terdapat hubungan antara fungsi otak dengan praktik pendidikan. Penelitian sebelumnya, BBL dapat memfasilitasi dan mempercepat pengembangan keterampilan berbicara (Khalil, El-nagar, \& Awad, 2019). Haghighi (2013) menemukan bahwa BBL dapat meningkatkan prestasi dan retensi siswa. Sedangkan penelitian ini juga menemukan bahwa terdapat efek intervensi pada kemampuan pemecahan masalah konsep bilangan dan secara statistik hasilnya meningkat signifikan. Perbedaan yang siginifikan $(\rho<0,05)$ dari nilai ratarata kelompok eksperimen pada saat pre-test dan post-test. Kelompok eksperimen yang diterapkan dengan brain based learning mendapatkan hasil yang memuaskan, baik pada komponen secara keseluruhan maupun disetiap komponennya. Demikian juga pada nilai rata-rata kelompok kontrol dan eksperimen. Perbedaan yang signifikan $(\rho<0,05)$ telihat pada rata-rata nilai kelompok eksperimen yang jauh lebih tinggi dari pada kelompok kontrol, baik secara keseluruhan maupun pada setiap komponennya. Hasil ini menunjukkan bahwa kemampuan pemecahan masalah konsep bilangan anak usia dini meningkat secara signifikan setelah diberikan perlakuan dengan brain based learning.

Anak-anak dari kelompok eksperimen telah menguasai kemampuan pemecahan masalah konsep bilangan yang ditargetkan: 1) Menyebut (mengucap bilangan, mengidentifikasi lambing bilangan), 2) Membilang (menghitung 1-20 benda), 3) Menghitung 
(menjumlahkan dan mengurangkan benda, 4) Mengelompokkan (mengelompokkan berdasarkan warna, bentuk, dan ukuran), 5) Membandingkan (membandingkan panjangpendek dan berat-ringan). Peningkatan kemampuan tersebut dikaitkan dengan penerapan strategi BBL yang efektif. Tahap BBL ke 2, yakni tahap Persiapan, pada tahap ini guru mengulang materi yang telah diajarkan sebelum masuk pada tahap apersepsi atau tahap selanjutnya. Hal ini sesuai dengan aliran psikologi tingkah laku (behaviorisme) dan konstruktivisme. Teori Ausubel terkenal dengan istilah belajar bermakna dan pentingnya pengulangan sebelum kegiatan pembelajaran dimulai (Ruseffendi, 1988: 172). Thorndike juga mengemukakan the law of exercise (hukum latihan) yang menunjukkan bahwa hubungan stimulus dan respon semakin kuat apabila terus-menerus dilatih dan diulang, begitupula sebaliknya hubungan stimulus respon akan semakin melemah apabila tidak pernah diulang (Hudojo, 1988: 12). Oleh karena itu, apabila semakin sering suatu pelajaran diulang kepada anak, maka akan semakin kuat anak menguasai pembelajaran tersebut.

BBL memberikan kesempatan kepada anak untuk belajar secara kelompok dan saling bekerjasama. Pada tahap ke 3 ini, yakni tahap inisasi dan akuisisi, anak-anak cukup antusias untuk memecahkan masalah. Tugas yang diberikan kepada setiap kelompok adalah menghitung jumlah benda dalam wadah. Setiap anggota kelompok saling bekerjasama, mereka membagi tugasnya masing-masing, seperti: ada bagian anak yang mengelompokkan sesuai karakteristik bendanya terlebih dahulu, anggota lain menghitung, dan yang lainnya menuliskan jumlahnya. Hal ini membuat anak-anak lebih senang daripada mengerjakan secara individu. Sesuai dengan strategi BBL yang mampu menciptakan suasana pembelajaran yang interaktif dan menyenangkan.

Tahap ke 4, yakni tahap Elaborasi merupakan tahap untuk menciptakan pembelajaran yang bermakna. Memberikan kesempatan pada otak untuk menyortir, menyelidiki, menganalisis, menguji dan memperdalam pembelajaran. Ketika telah selesai tugasnya, setiap kelompok diminta menjelaskan hasil kerjanya di depan kelas secara bergantian. Kelompok yang belum mendapatkan giliran maju dapat memperhatikan temannya yang sedang maju. Anak yang mendapatkan giliran di depan memperlihatkan hasil dari jumlah benda yang telah di hitung, guru memandu diskusi ini. Guru mengajak seluruh anak berhitung nyaring untuk mencocokan hasil benda yang telah di hitung. Dengan demikian, tercipta diskusi sederhana pada anak dan suasana pembelajaran menjadi lebih aktif.

Tahap ke 5 inkubasi dan memasukkan memori, merupakan tahap yang menekankan pentingnya waktu istirahat dan pengulangan. Otak akan lebih lebih efektif bekerja apabila belajar dari waktu ke waktu, bukan sekaligus dalam satu waktu. Setelah selesai mempresentasikan atau mendiskusikan hasil tugasnya di depan kelas, anak-anak diberikan waktu untuk beristirahat. Anak-anak menikmati istirahatnya dengan makan dan mendengarkan musik. Guru memberikan makanan yang bergizi pada anak dan menghidupkan musik yang menenangkan, seperti musik instumental atau musik anak yang gembira. Hal ini memberikan kesempatan kepada otak untuk beristirahat sejenak.

Selanjutnya, di tahap 6 verifikasi dan pengecekkan keyakinan, guru mengulas pembelajaran dengan memberikan pertanyaan-pertanyaan ke pada anak. Hal ini untuk menggali pemahaman anak terhadap materi yang telah diberikan sebelumnya. Pada kelas eksperimen anak terlihat cukup semangat, mereka berebut ingin menjawab pertanyaan yang diberikan oleh guru. Seperti "berapa banyak terong, brokoli, dan kubis di dalam wadah tadi?", "Berapa jumlah sayuran yang berwarna oren?", "Sayuran apa saja yang berwarna hijau dan berapa jumlahnya?" Anak usia dini sangat senang kegiatan pembelajaran yang dikaitkan dengan permainan, mereka menganggap bahwa apa yang mereka lakukan, seperti: menghitung benda atau mainan dalam keranjang tersebut bukan merupakan suatu tugas, melainkan sebuah permainan yang mengasyikkan bagi mereka. 
Tahap ke enam, perayaan dan integrasi merupakan tahap menanamkan arti penting kecintaan terhadap belajar. Di akhir pembelajaran ini, anak-anak yang berasal dari kelompok eksperimen mengungkapkan perasaannya masing-masing. Guru memandu dengan pertanyaan, "Bagaimana perasaan anak-anak hari ini? Apakah senang belajarnya?". Selain itu, guru juga memberikan reward kepada anak yang telah mengerjakan tugasnya. Pada tahap ini, guru juga menempelkan hasil karya anak. Hal ini sebagai wujud apresiasi terhadap hasil kerja anak.

Saat kelompok eksperimen diberikan tretament, mereka diajarkan bagaimana cara memecahkan masalahnya secara sederhana. Pada komponen membandingkan, treatment yang diberikan adalah mengajari anak bagaimana membedakan panjang-pendek dengan alat ukur tidak standar. Misalnya mengukur meja dengan jengkal tangan, sambil dihitung nyaring berapa jumlah jengkalnya; membedakan panjang pendek pita dengan menghitung langkah kaki di atas pita; dan membedakan panjang pendek benda dengan cara mengurutkan dari yang terbesar hingga kecil. Kelompok eksperimen menggunakan mediamedia yang konkrit, berbeda dengan kelompok kontrol yang ketika mengajarkan konsep bilangan menggunakan lembar kerja anak. Treatment yang diberikan ini juga sebagai upaya apabila dalam keseharian anak mendapatkan permasalahan, ia dapat memecahkannya sendiri dengan cara yang fleksibel.

\section{SIMPULAN}

Brain based learning cukup berhasil dalam meningkatkan pemecahan masalah konsep bilangan anak usia dini yaitu menyebut, membilang, menghitung, mengelompokkan, dan membandingkan. Pendekatan yang cukup efektif ini dapat memfasilitasi dan mempercepat penyampaian pembelajaran kepada anak, sehingga sangat perlu diterapkan di sekolah Indonesia yang mungkin mayoritas masih menggunakan pendekatan tradisional dalam mengajar. Brain based learning dapat diterapkan pada berbagai macam pembelajaran dan pendekatan ini menciptakan pembelajaran yang berpusat pada siswa.

\section{UCAPAN TERIMAKASIH}

Penulis berterima kasih kepada Bapak Harun untuk membimbingnya menyelesaikan penelitian ini, dan juga berterima kasih kepada Universitas Negeri Yogyakarta untuk fasilitasi yang mendukung pengaturan artikel ini.

\section{DAFTAR PUSTAKA}

Astuti. (2016). Peningkatakan kemampuan anak mengenal konsep bilangan melalui permainan kartu angka di kelompok B TK Aisyiyah Pulau Payung Kecamatan Rumbio Jaya. Jurnal PAUD Tambusai, 2(1), 90-99. https://doi.org/10.31004/obsesi.v2i1.63

Blake, S., Hurley, S., \& Arenz, B. (1995). Mathematical problem solving and young children. Early Childhood Education Journal, 23(2), 81-84. https://doi.org/https://doi.org/10.1007/BF02353397

Chamidiyah. (2015). Pembelajaran melalui brain based learning dalam pendidikan anak usia dini. Edukasia: Jurnal Penelitian Pendidikan Islam, 10(2), 279-300. Retrieved from http://dx.doi.org/10.21043/edukasia.v10i2.795

Cohen, J. (1988). Statistical Power Analysis for the Behavioral Sciences Second Edition. https://doi.org/https://doi.org/10.4324/9780203771587

Fauziddin, M. (2015). Peningkatan kemampuan matematika anak usia dini melalui permainan jam pintar di taman kanak-kanak pembina kec. Bangkinang Kota. Jurnal PAUD Tambusai, 1(1), 49-54. https://doi.org/10.31004/obsesi.v1i1.55 
Haghighi, M. (2013). The effect of brain- based learning on Iranian EFL achievement and retention. Procedia - Social and Behavioral Sciences, 70, 508-516. https:// doi.org/10.1016/j.sbspro.2013.01.088

Hudojo, H. (1988). Mengajar belajar matematika. Jakarta: Depdikbud.

Jensen, E. (2008). Brain-based learning: The new paradigm of teaching. Corwin Press.

Khalil, A. H., El-nagar, B. E. E., \& Awad, M. A. E. (2019). The effect of brain-based learning on developing some speaking skills of Egyptian EFL Secondary School Students. International Journal of Environmental and Science Education, 14(3), 103-116. Retrieved from http://www.ijese.net/makale_indir/2107

Maloney, E. A., Schaeffer, M. W., \& Beilock, S. L. (2013). Mathematics anxiety and stereotype threat : shared mechanisms, negative consequences and promising interventions. Research in Mathematics Education, 15(2), 115-128. https:/ / doi.org/10.1080/14794802.2013.797744

Piaget, J. (1977). Problems of equilibration (Topics in; M. H. Appel \& L. S. Goldberg, eds.). Retrieved from https:/ / doi.org/10.1007/978-1 4613-4175-8_1

Polonsky, L., Freedman, D., Lesher, S., \& Morrison, K. (1995). Math for the very young: A handbook of ac-tivities for parents and teachers. New York: Wiley.

Ramirez, G., Gunderson, E. A., Levine, S. C., \& Beilock, S. L. (2013). Math anxiety , working memory, and math achievement in early elementary school math anxiety, working memory, and math achievement in early elementary school. Journal of Cognition and Develop-Ment, 14(2), 187-202. https:// doi.org/10.1080/15248372.2012.664593

Rianti, W. (2016). Meningkatkan kemampuan mengenal lambang bilangan melalui permainan tata angka pada anak usia dini. Jurnal PAUD Tambusai, 2(2), 36-42. https:// doi.org/10.31004/obsesi.v2i2.40

Ruseffendi. (1988). Pengantar kepada membantu guru mengem-bangkan kompetensinya dalam pengajaran matematika untuk meningkatkan CBSA. Bandung: Tarsito.

Santoso, A. (2010). Studi deskriptif effect size penelitian-penelitian di fakultas psikologi Universitas Sanata Dharma. Jurnal Penelitian, 14(1), 1-17.

Smith, A. M., Cotton, T., Hansen, A., \& Price, A. J. (2018). Mathematics in Early Years Education (fourth). Retrieved from http://93.174.95.29/main/2229000/b9f2c192a3abd0135b58472d72ee3938/Ann Monta-gue-Smith\%2C Tony Cotton\%2C Alice Hansen\%2C Alison J. Price Mathematics in Early Years Education-Routledge \%282017\%29.pdf

Tüfekçi, S., \& Demirel, M. (2009). The effect of brain based learning on achievement, retention, attitude and learning process. Procedia Social and Behavioral Sciences, 1(1), 1782-1791. https:// doi.org/10.1016/j.sbspro.2009.01.316

Xin, Y. P., Wiles, B., \& Lin, Y. (2008). Teaching conceptual model-based word problem story grammar to enhance. The Journal of Special Education, 42(3), 163-178. Retrieved from https:/ / doi.org/10.1177/0022466907312895 